\title{
Eletroencefalografia quantitativa em indivíduos saudáveis e pacientes pós-ave crônico: um estudo transversal
}

\section{Quantitative electroencephalography in healthy individuals and chronic stroke patients: a cross- sectional study}

\author{
Marília Austregésilo Saraiva da Silva ${ }^{1}$ (]) \\ Rodrigo de Mattos Brito 2 (1) \\ Maíra Izzadora Souza Carneiro ${ }^{3}$ (1) \\ Adriana Baltar do Rego Maciel ${ }^{4}$ (1)
}

\author{
Alexia de Deus Perruci ${ }^{5}$ (1) \\ João Victor Fabrício Vieira de Melo $^{6}$ (1) \\ André Ricardo Oliveira Fonseca7 (1) \\ Kátia Monte-Silva ${ }^{8}$ (1)
}

\begin{abstract}
${ }^{1}$ Autora para correspondência. Centro de Ciências da Saúde, Departamento de Fisioterapia, Laboratório de Neurociência Aplicada, Universidade Federal de Pernambuco (Recife). Pernambuco, Brasil. mariliap997@gmail.com ${ }^{2-6,8}$ Centro de Ciências da Saúde, Departamento de Fisioterapia, Laboratório de Neurociência Aplicada, Universidade Federal de Pernambuco (Recife). Pernambuco, Brasil.rmbrito1@gmail.com, adrianabaltarmaciel@gmail.com, mairasouza77@gmail.com, alexia.perruci@gmail.com, joaovmelo2015@gmail.com, monte.silvakk@gmail.com ${ }^{7}$ Centro de Matemática, Computação e Cognição, Instituto de Física Teórica, Universidade Federal do ABC (São Bernardo do Campo). São Paulo, Brasil.
\end{abstract} andre.fonseca@ufabc.edu.br

RESUMO | INTRODUÇÃO: O Acidente Vascular Encefálico (AVE) altera a atividade elétrica cortical do cérebro ${ }^{1}$. Acredita-se que o padrão de alteração pode variar de acordo com o nível de comprometimento sensório-motor e com a fase de recuperação - aguda ou crônica. Nesse sentido, medidas quantitativas eletroencefalográficas (qEEG) podem servir como biomarcadores e mensurar com uma alta precisão temporal o padrão de atividade cortical pós-AVE ${ }^{2,3}$. Dentre estas medidas, pode-se utilizar o Power Ratio Index (PRI), que se refere à razão entre a média do poder espectral relativo das bandas de frequência lentas (delta e teta) e rápidas (alfa e beta). Dessa forma, quanto maior o PRI, mais lentificada é a atividade elétrica cortical do cérebro4. Até agora, nenhum estudo se objetivou em identificar padrões de alteração na atividade elétrica cortical consideran- do alterações sensório-motoras pós-AVE crônico e comparando os achados com dados de indivíduos saudáveis. OBJETIVO: Identificar diferenças no padrão de atividade elétrica cortical utilizando o PRI em pacientes pós-AVE crônico e indivíduos saudáveis, considerando o grau de comprometimento sensório-motor dos pacientes. MATERIAIS E MÉTODOs: Estudo transversal aprovado pelo Comitê de Ética em Pesquisa do Centro de Ciências da Saúde da Universidade Federal de Pernambuco (CEP/CCS/UFPE: 446.016). O tamanho da amostra foi mensurado a partir de um cálculo posteriori tendo como base a média e desvio padrão do índice Power Ratio Index do grupo de pacientes pós-AVE e indivíduos saudáveis (ver tabela 1). Considerando um poder de erro probabilístico $(\beta)$ de $80 \%$ e um nível de significância (a) de 95\%, foi necessário no mínimo 14 
pacientes pós-AVE e 14 voluntários saudáveis. O cálculo amostral foi feito através do software $G *$ Power 3.1.9.7. A amostra constituía-se de: (i) 47 pacientes pós-AVE crônico sendo 25 com comprometimento sensório-motor leve ou moderado e 22 com comprometimento sensório-motor grave e (ii) 12 indivíduos saudáveis. Os critérios de inclusão foram: (i) pacientes de ambos os gêneros; (ii) com idade entre 18 e 75 anos; (iii) com diagnóstico de AVE hemorrágico ou isquêmico; (iv) com tempo de lesão $\geq 3$ meses e (v) com presença de sequelas sensório-motoras em membro superior avaliadas através da Escala de Fugl-Meyer $\mathrm{EFM}^{5}$. Os critérios de exclusão foram: (i) presença de outro tipo de distúrbio neurológico ou psiquiátrico e (ii) déficit cognitivo grave avaliado pelo Mini Exame do Estado Mental (< 18 pontos) $)^{6}$. Para a população de indivíduos saudáveis, foram incluídos voluntários que se auto declararam saudáveis, os quais foram pareados por idade e sexo com os voluntários do grupo de pacientes pós-AVE. A classificação do grau de severidade sensório-motora dos pacientes adotado foi: (i) comprometimento leve/moderado $>19$ pontos na EFM e (ii) comprometimento severo < 19 pontos na $\mathrm{EFM}^{\mathrm{T}}$. Inicialmente, os voluntários foram orientados sobre como seria realizado o exame de EEG. A aquisição do EEG teve duração total de um minuto. Durante a aquisição, o paciente/voluntário esteve sentado confortavelmente em uma cadeira, em estado de repouso, relaxado e com olhos abertos sem qualquer comunicação. O sinal de EEG foi captado através de nove canais posicionados nos pontos F3, C3, P3, Fz, Cz, Pz, F4, C4 e P4, seguindo o sistema de marcação 10-20 de eletroencefalografia. A taxa de amostragem de $500 \mathrm{~Hz}$ foi subdivida em 30 janelas livres de artefatos. Inicialmente, o poder absoluto de cada canal foi calculado. Em seguida, foi realizada a relativização do poder para mensuração do PRI, em conjunto com uma análise descritiva utilizando média e desvio padrão para quantificação do índice PRI em ambos os grupos (pacientes e indivíduos saudáveis). Uma vez confirmada a normalidade dos dados através do teste de Kolmogorov-Smirnov, o teste $t$ para amostras independentes foi utilizado para comparar o PRI dos pacientes pós-AVE (sem considerar o grau de comprometimento sensório-motor) com o PRI de indivíduos saudáveis. Adicionalmente, o teste de ANOVA one-way foi utilizado para comparação entre o grau de comprometimento sensório-motor e indivíduos saudáveis (leve/moderado vs. Grave vs. Indivíduos saudáveis) com post-hoc de Tukey. Adicionalmente, foi constatado o poder da análise $(\beta>80 \%)$ da ANOVA para verificar se 0 tamanho amostral foi suficiente para responder à questão clínica. Por fim, foi considerado um $p \leq 0,05$. Toda análise foi realizada através do software SPSS V23.0. RESULTADOS: Através do poder de análise do teste ANOVA one-way $(\beta=0,91)$ é possível observar que a amostra utilizada neste estudo é suficiente para responder à questão clínica. O teste t para amostras independentes, sem considerar os graus de comprometimento sensório-motor, mostrou uma lentificação da atividade cerebral $(t=3,41 ; p<0,001)$ em pacientes pós-AVE (PRI $=2,71 \pm 0,51)$ quando comparados com voluntários saudáveis $(\mathrm{PRI}=2,10$ $\pm 0,71$ ). Além disso, observou-se uma lentificação da atividade elétrica cerebral após comparar os pacientes de acordo com o grau de comprometimento sensório-motor $(F(1.06,48.6)=10.74 ; p=0.02 ;$ Power $(\beta)$ $=0.91$ ) leve $/$ moderado (PRI $=2,60 \pm 0,41$; Post-hoc Tukey $p=0,03$ ) e grave (PRI $=2,84 \pm 0,59$; Post-hoc Tukey $p=0,002$ ) quando comparados com voluntários saudáveis. Por fim, o post-hoc de Tukey revelou que não há diferença na atividade elétrica cortical de pacientes com comprometimento sensório-motor severo em comparação com comprometimento leve/moderado ( $p=0,118)$ (tabela 1). DISCUSSÃO: Apesar de não atingir o cálculo amostral necessário, o poder do teste da ANOVA one way foi aceitável para a comparação proposta. Os resultados apontam para uma lentificação da atividade cerebral em pacientes pós-AVE crônico quando comparados com voluntários saudáveis. Uma lesão estrutural, decorrente da morte do tecido cerebral, pode alterar o padrão de atividade de conexões neurais excitatórias e inibitórias, as quais geralmente estão balanceadas em indivíduos saudáveis e sofrem alterações após um ictus ${ }^{1}$. Através de conexões inter-hemisféricas, pacientes pós-AVE podem apresentar uma diminuição na excitabilidade cortical do hemisfério lesado e um aumento na do hemisfério saudável ${ }^{*}$. A alteração do balanço da atividade elétrica cortical entre os hemisférios lesado e saudável nesses pacientes parece relacionar-se com o nível de comprometimento sensório-motor e com a capacidade de recuperação deles $\stackrel{9}{ }$. Entretanto, o presente estudo não apontou diferença entre atividade elétrica cortical em pacientes com comprometimento sensório-motor severo quando comparados com aqueles com comprometimento leve/moderado. Nesse sentido, uma limitação do estudo foi o pequeno número de canais utilizados no qEEG, o que pode ter contribuído para tal desfecho, já que a extensão e localização da lesão no hemisfério lesado não foi totalmente abrangida ${ }^{10}$. 
Tabela 1. Índice Power Ratio Index (média \pm desvio padrão) em paciente pós-AVE com comprometimento sensório-motor e voluntários saudáveis

\begin{tabular}{|c|c|c|c|c|c|}
\hline & \multirow[b]{2}{*}{ Voluntário Saudável } & \multirow[b]{2}{*}{$\begin{array}{l}\text { Paciente pós- } \\
\text { AVE }\end{array}$} & \multicolumn{2}{|c|}{$\begin{array}{l}\text { Grau de comprometimento sensório- } \\
\text { motor }\end{array}$} & \multirow[b]{2}{*}{$\begin{array}{c}\beta \\
\text { (poder ANOVA) }\end{array}$} \\
\hline & & & Leve/moderado & Grave & \\
\hline $\begin{array}{l}\text { Power Ratio Index } \\
\text { (PRI) }\end{array}$ & $2,10 \pm 0,71$ & $2,71 \pm 0,51 *$ & $2,60 \pm 0,41 *$ & $2,84 \pm 0,59 *$ & 0,91 \\
\hline
\end{tabular}

* diferença estatística $(p<0,05)$ quando comparado com voluntários saudáveis.

CONCLUSÃO: Quando comparados a indivíduos saudáveis, pacientes pós-AVE crônicos apresentam uma lentificação da atividade elétrica cortical que não é dependente do nível de comprometimento motor deles. Além disso, o PRI não parece ser capaz de identificar padrões de atividade elétrica cortical diversos quando se leva em consideração o nível de comprometimento sensório-motor de pacientes pós-AVE crônico (leve/moderado vs. severo).

PALAVRAS-CHAVE: Eletroencefalografia. Acidente Vascular Cerebral. Power Ratio Index.

ABSTRACT | INTRODUCTION: Stroke changes the cortical electrical activity ${ }^{1}$. The pattern of such change may vary according to the level of sensorimotor impairment and also with the recovery phase - acute or chronic. Thus, quantitative electroencephalography measures ( $q E E G$ ) may be used as biomarkers to quantify the pattern of poststroke cortical activity with the advantage of having a high temporal precision 2,3 . Among these qEEG measures, the Power Ratio Index (PRI) stands out as a promising biomarker option. Such index refers to the ratio between the mean of relative spectral power of the slow (delta and theta) and fast (alpha and beta) frequency bands. Thus, the higher the PRI, the slower the cortical electrical activity. However, few studies, so far, have used the PRI to identify changes in cortical electrical activity according to sensorimotor impairments shown by chronic stroke patients and, few of them confronted such data with "normal" data of healthy individuals. OBJECTIVE: To identify differences in cortical electrical activity using PRI in chronic stroke patients and healthy individuals, considering the severity of sensorimotor impairments of such patients. MATERIALS AND METHODS: A crosssectional study was performed after approval of the Research Ethics Committee, Health Sciences Center, Federal University of Pernambuco (CEP / CCS / UFPE: 446.016). The sample size was post-measured based on the mean and standard deviation of the Power Ratio Index of the group stroke and patients (see table 1). Considering a probabilistic error power ( $\beta$ ) of $80 \%$ and a significance level (a) of $95 \%$, it was necessary at least 14 stroke patients and 14 healthy volunteers. The sample calculation was done using the $G$ * Power 3.1.9.7 software. The chronic stroke patients' sample was composed of 47 individuals: 25 out of them with mild or moderate sensorimotor impairment and 22 out of them with severe sensorimotor impairment; the healthy individual's group was composed of 12 healthy individuals. Inclusion criteria were: (i) patients of both genders; (ii) with age between 18 and 75 years; (iii) with a diagnosis of hemorrhagic or ischemic stroke; (iv) with injury-time $\geq 3$ months and (v) with the presence of sensorimotor impairments in the upper limb assessed through the Fugl-Meyer Assessment - FMA ${ }^{5}$. Exclusion criteria were: (i) presence of another type of neurological or psychiatric disorder and (ii) severe cognitive impairment assessed through the Mini-Mental State Examination ( $<18$ points $)^{6}$. The healthy individuals' group was composed of volunteers who considered themselves as healthy, and who were paired by age and sex with the chronic stroke patients. The severity of sensorimotor impairment presented by stroke patients was defined as follows: (i) mild/moderate sensorimotor impairment $>19$ points in FMA and (ii) severe sensorimotor impairment $<19$ points in FMA ${ }^{7}$. EEG was recorded for 60 seconds in an isolated room with a volunteer with eyes opened and seated in a comfortable armchair. The EEG signal was recorded through nine channels positioned at F3, C3, P3, Fz, Cz, Pz, F4, C4, and P4, following the 10-20 EEG system. EEG data file was recorded at a sample rate of $500 \mathrm{~Hz}$ and segmented into 30 data points. Initially, the absolute power of each channel was calculated, followed by a relativization power measurement to calculate the PRI. Then, a descriptive analysis was performed using means and standard deviations to quantify the PRI index in both groups (chronic stroke patients and healthy individuals). Once data do not violate normality (assessed through the Kolmogorov-Smirnov test), a t-test for 
independent samples was used to compare the PRI index of chronic stroke patients (without considering the severity of sensorimotor impairment) with the PRI index of healthy individuals. Additionally, the ANOVA one-way with Tukey posthoc was used to compare the severity of sensorimotor impairment of patients (mild/moderate vs. severe) with healthy individuals (mild/moderate vs. healthy; and, severe vs. healthy). Finally, an ANOVA power $(\beta>80 \%)$ was analyzed to assume a good sample size was considered a $p \leq 0.05$. All analysis was performed through software SPSS v23.0. RESULTS: The Power of ANOVA one way $(\beta=0,91)$ shows a good sample size. $t$ test for independent samples, without considering the severity of sensorimotor impairment of chronic stroke patients, showed a slowdown brain activity ( $t=3.41 ; p<0.001)$ in such patients ( $P R I=2.71 \pm 0.51)$ when compared to healthy individuals $(P R I=2.10 \pm 0.71$ ). It was possible to identify also a slowdown electrical brain activity in chronic stroke patients taking into account the severity of sensorimotor impairment $(F(1.06,48.6)=10.74 ; p=0.02$; Power $(\beta)$ $=0.91)$ : mild / moderate impairment $(\mathrm{PRI}=2,60 \pm 0,41$; Post-hoc Tukey $p=0,03)$ and severe impairment $(\mathrm{PRI}=$ $2,84 \pm 0,59$; Post-hoc Tukey $p=0,002$ ) when compared to healthy individuals. T test for independent samples also revealed that there is no difference in the cortical electrical activity of patients with severe sensorimotor impairment when compared to those with mild / moderate impairment $(p=0.118)$ (see Table 1). DISCUSSION: Results point out a slowdown of brain activity in chronic stroke patients when compared to healthy individuals. A brain lesion, the result of the death of brain tissue, can alter the activity pattern of excitatory and inhibitory neural connections, which are generally balanced in healthy individuals and undergo changes after an ictus ${ }^{1}$. Through inter-hemispheric connections, post-stroke patients may experience a decrease in cortical excitability of the injured hemisphere and an increase in the cortical electrical activity of the non-injured hemisphere ${ }^{8}$. The change in the balance of cortical electrical activity between the injured and the non-injured hemispheres in poststroke patients seems to be related to the level of sensorimotor impairment and their recovery capacity ${ }^{9}$. Besides that, the present study also pointed out an absence of difference between cortical electrical activity in patients with severe sensorimotor impairment when compared with those with mild/moderate impairment. However, a limitation of this study was the small number of channels used in GEEG, which may have contributed to these results, since the extent and location of the lesion in the injured hemisphere were not fully covered ${ }^{10}$.

Table 1. Power Ratio Index (mean \pm standard deviation) of chronic stroke patients presented according to the severity of sensorimotor impairment vs. healthy individuals

\begin{tabular}{|c|c|c|c|c|c|}
\hline & \multirow[b]{2}{*}{ Healthy Individuals } & \multirow[b]{2}{*}{$\begin{array}{l}\text { Post-stroke } \\
\text { patient }\end{array}$} & \multicolumn{2}{|c|}{ Sensorimotor impairment } & \multirow[b]{2}{*}{$\begin{array}{c}\beta \\
\text { (ANOVA power) }\end{array}$} \\
\hline & & & Mild / moderate & Severe & \\
\hline $\begin{array}{l}\text { Power Ratio Index } \\
\text { (PRI) }\end{array}$ & $2,10 \pm 0,71$ & $2,71 \pm 0,51 *$ & $2,60 \pm 0,41 *$ & $2,84 \pm 0,59 *$ & 0,91 \\
\hline
\end{tabular}

*statistical difference $(p<0.05)$ when compared to healthy individuals.

CONCLUSION: When compared to healthy individuals, chronic stroke patients have a slowdown of cortical electrical activity, which seems to be not dependent on their level of sensorimotor impairment. Furthermore, unfortunately, the PRI index does not seem to be able to identify different patterns of cortical electrical activity when taking into account the levels of sensorimotor impairment in chronic stroke patients

KEYWORDS: Power Ratio Index. Stroke. Electroencephalography. 


\section{Contribuições dos autores}

Silva MAS participou da elaboração do trabalho escrito. Brito RM e Maciel ABR foram responsáveis pela coleta dos dados, análise estatística e elaboração do trabalho escrito. Carneiro MIS participou da elaboração e revisão do trabalho escrito. Perruci AD e Melo JVFV participaram da elaboração do trabalho escrito. Fonseca ARO ficou responsável pelo tratamento e estatística dos dados e Monte-Silva $\mathrm{K}$ foi idealizadora e ficou responsável pela revisão final do artigo científico. Idealização e revisão do trabalho.

\section{Conflitos de interesses}

Nenhum conflito financeiro, legal ou político envolvendo terceiros (governo, empresas e fundações privadas, etc.) foi declarado para nenhum aspecto do trabalho submetido (incluindo, mas não se limitando a subvenções e financiamentos, participação em conselho consultivo, desenho de estudo, preparação de manuscrito, análise estatística, etc.).

\section{Referências}

1. Wu P, Zeng F, Li Y, Yu B, Qiu L, Qin W, et al. Changes of resting cerebral activities in subacute ischemic stroke patients. Neural Regen Res. 2015;10(5):760-5. https://doi.org/10.4103/1673$\underline{5374.156977}$

2. Bentes C, Peralta AR, Viana P, Martins H, Morgado C, Casimiro $C$, et al. Quantitative EEG and functional outcome following acute ischemic stroke. Clin Neurophysiol. 2018;129(8):1680-7. https:// doi.org/10.1016/j.clinph.2018.05.021

3. Trujillo P, Mastropietro A, Scano A, Chiavenna A, Mrakic-Sposta $\mathrm{S}$, Caimmi $\mathrm{M}$, et al. Quantitative EEG for predicting upper limb motor recovery in chronic stroke robot-Assisted rehabilitation. IEEE Trans Neural Syst Rehabil Eng. 2017;27(5):1058-67. https:// doi.org/10.1109/tnsre.2017.2678161
4. Nagata K, Gross CE, Kindt GW, Geier JM, Adey GR. Topographic electroencephalographic study with power ratio index mapping in patients with malignant brain tumors. Neurosurgery. 1985;17(4):613-9. https://doi.org/10.1227/00006123-198510000$\underline{00014}$

5. Duncan PW. Outcome measures in stroke rehabilitation. In: Barnes MP, Good DC, editores. Handbook of Clinical Neurology. Vol. 100. Amsterdam (The Netherlands): Elsevier B.V.; 2013.

6. Cockrell JR, Folstein MF. Mini-Mental State Examination (MMSE). Psychopharmacol Bull. 1988;24(4):689-92. Citado em: PMID: $\underline{3249771}$

7. Woodbury ML, Velozo CA, Richards LG, Duncan PW. Rasch Analysis Staging Methodology to Classify Upper Extremity Movement Impairment After Stroke. Arch Phys Med Rehabil. 2013;94(8):1527-33. https://doi.org/10.1016/j.apmr.2013.03.007

8. Nowak DA, Grefkes C, Ameli M, Fink GR. Interhemispheric Competition After Stroke: Brain Stimulation to Enhance Recovery of Function of the Affected Hand. Neurorehabil Neural Repair. 2009;23(7):641-56. https://doi.org/10.1177\%2F1545968309336661

9. Grefkes C, Fink GR. Connectivity-based approaches in stroke and recovery of function. Lancet Neurol. 2014;13(2):206-16. https://doi.org/10.1016/S1474-4422(13)70264-3

10. Leon-Carrion J, Martin-Rodriguez JF, Damas-Lopez J, Barroso y Martin JM, Dominguez-Morales MR. Delta-alpha ratio correlates with level of recovery after neurorehabilitation in patients with acquired brain injury. Clin Neurophysiol. 2009;120(6):1039-45. https://doi.org/10.1016/j.clinph.2009.01.021 